\title{
Swings of Sugars in COVID Era
}

\author{
Rutul Gokalani ${ }^{1} \quad$ Dharmendra Panchal2,๑ \\ ${ }^{1}$ AHC Diabetes Clinic, Ahmedabad, Gujarat, India \\ ${ }^{2}$ DiaCare - Diabetes and Hormone Clinic, India
}

J Soc Health Diab:2020;8:29-30

The chronic condition such as type 2 diabetes mellitus (T2DM) can be managed well with certain positive adaptations to lifestyle and antidiabetic medications. This is the core responsibility of the patient with the collective efforts by a doctor, a dietician, and an educator to improve the life of the patient by prescribing appropriate medicines, by setting the dietary goal, and providing the understanding of the disease. Adherence to this regimen makes it easier to maintain or achieve the long-term desired health outcomes.

The lockdown situation forced everyone to restrict their routine activity and stay indoors. This scenario came up with an opportunity for few patients with T2DM to introspect the gaps and to improve their habits with diet, exercise, and to excel the compliance with medications and self-glucose monitoring. Many of them tried almost all possible measures to have a good glycemic control, which reflected in their hemoglobin A1c values. These values were at their worst prior to the pandemic. In addition, even the fact and/or fear that they belong to the vulnerable group forced them to be extra cautious. Nevertheless, this helped them to achieve the longing unachieved glycemic targets. Conversely, in the other chunk of T2DM patients, the outcome of this situation was worse. Their glycemic status was flipped from good to never seen worse. The probable causes of this have been sedentary
Address for correspondence Rutul Gokalani, MD, AHC Diabetes Clinic, 101, First Floor, Trade Square, Opp. Torrent Power Station, Sabarmati, Ahmedabad 380005, Gujarat, India (e-mail: ruturaj.9560@gmail.com).

life, stress, no visits to doctors, continuing same medication, fear of getting coronavirus infection. During this period, binge-eating became a larger issue as foodie people came up with series of newer and interesting recipes every day; it became a campaign or competition on social media for few months, which resulted in weight gain for many and that led to poor glycemic picture in people with T2DM. In addition, dependence on social media that gave everything within no time on their screen made individual lazier than before. This describes the two different outlooks on same situation by T2DM individuals.

The factors that helped in achieving the glycemic target were inadequately performed prior to the corona pandemic, may be due to negligence, insufficient time, or any other reasons. To them who had inadequate time to manage disease took this period to improve their health status. To the negligent, the situation might have not affected. As it is said that how we look at the situations makes a difference. Some people see the glass half full, and others see it half empty. The same was noticed in case of T2DM patients when lockdown was imposed.

- Tables 1 to 3 and -Fig. 1 describe our experience in "Swings of Sugar" through comparison between two similar cases having the different outcomes.
DOI https://doi.org/ $10.1055 / \mathrm{s}-0040-1722420$ ISSN 2321-0656.
(C) 2020. Novo Nordisk Education Foundation.

This is an open access article published by Thieme under the terms of the Creative Commons Attribution-NonDerivative-NonCommercial-License, permitting copying and reproduction so long as the original work is given appropriate credit. Contents may not be used for commercial purposes, or adapted, remixed, transformed or built upon. (https://creativecommons.org/licenses/by-nc-nd/4.0/).

Thieme Medical and Scientific Publishers Pvt. Ltd. A-12, 2nd Floor, Sector 2, Noida-201301 UP, India 
Table 1 Comparison of anthropometric data and glycemic status of two patients ${ }^{\mathrm{a}}$

\begin{tabular}{|c|c|c|}
\hline & Patient A (with the good outcome) & Patient B (with the bad outcome) \\
\hline Age & $63 y$ & $65 y$ \\
\hline Duration of diabetes & $22 \mathrm{y}$ & $26 y$ \\
\hline Weight (before lockdown) & $95.6 \mathrm{~kg}$ & $92.7 \mathrm{~kg}$ \\
\hline Weight (after lockdown) & $90.3 \mathrm{~kg}$ & $93.3 \mathrm{~kg}$ \\
\hline BMI & 29.9 & 30.7 \\
\hline HbA1c (before lockdown) & $8 \%$ & $6.5 \%$ \\
\hline HbA1c (after lockdown) & $5.3 \%$ & $9.2 \%$ \\
\hline Medication & $\begin{array}{l}\text { Multiple OADs including SUs (with optimal } \\
\text { dose) }\end{array}$ & $\begin{array}{l}\text { Multiple OADs including SUs (with optimal } \\
\text { dose) }\end{array}$ \\
\hline Follow-up pattern & $\begin{array}{l}\text { Two visits via telemedicine during lockdown } \\
\text { and immediate visit at clinic after lockdown }\end{array}$ & Not in contact with HCP during lockdown \\
\hline
\end{tabular}

Abbreviations: HbA1c, hemoglobin A1c; HCP, health care provider; OADs, oral antidiabetic drugs; SU, sulfonylureas.

${ }^{a}$ Details of two patients with similar characteristics and different glycemic response.

Table 2 Swings of sugar-I

\begin{tabular}{|l|l|l|l|l|}
\hline Test name & October 27, 2017 & February 7, 2018 & August 21, 2019 & August 18, 2020 \\
\hline FBS & 191 & 161 & & 109 \\
\hline PPBS & 280 & & 199 & 5.3 \\
\hline HbA1C \% & 8.4 & 7.7 & 8.0 & 183 \\
\hline Mean blood glucose & & 174 & 105 \\
\hline
\end{tabular}

Abbreviations: FBS, fasting blood sugar; HbA1c, hemoglobin A1c; PPBS, postprandial blood sugar.

Table 3 Swings of sugar-II

\begin{tabular}{|l|l|l|l|l|l|}
\hline Test name & $\begin{array}{l}\text { November 19, } \\
\mathbf{2 0 1 8}\end{array}$ & $\begin{array}{l}\text { December 12, } \\
\mathbf{2 0 1 8}\end{array}$ & $\begin{array}{l}\text { April 15, } \\
\mathbf{2 0 1 9}\end{array}$ & $\begin{array}{l}\text { October 5, } \\
\mathbf{2 0 1 9}\end{array}$ & $\begin{array}{l}\text { August 2, } \\
\mathbf{2 0 2 0}\end{array}$ \\
\hline RBS & & 100 & & & 253 \\
\hline HbA1C \% & 6.8 & 6.9 & 7.0 & 6.5 & 9.2 \\
\hline Mean blood glucose & 148 & 151 & 154 & 139 & 253 \\
\hline
\end{tabular}

Abbreviations: HbA1c, HbA1c, hemoglobin A1c; RBS, random blood sugar.

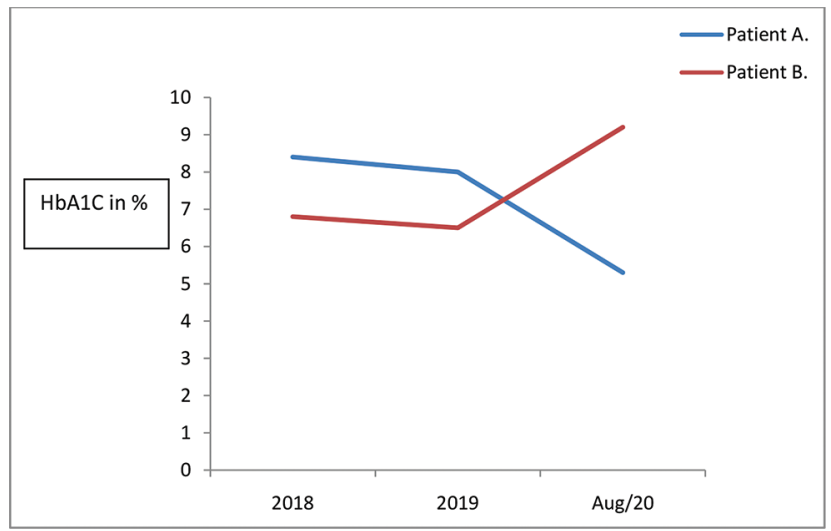

Fig. 1 First visit after lockdown. Patient $A$ achieved the due target hemoglobin $\mathrm{A} 1 \mathrm{c}(\mathrm{HbA} 1 \mathrm{C})$ since many years. Patient $\mathrm{B}$ ended up with worst glycemic status of his life.
To conclude, it can be said that this pandemic affected the glucose targets of people living with T2DM. Further research is needed in this direction to study the glycemic control in patients with T2DM during lockdown and to understand the behavior pattern of patients living with diabetes during coronavirus disease (COVID). In addition, we are of the opinion that a positive outlook toward the situation proved good for the health and helped in managing the glucose levels.

\section{Conflict of Interest}

None declared. 